\title{
Sweetgum: a new look
}

\author{
Joshua P Adams ${ }^{(1)}$, Jody $M$ \\ Lingbeck $^{(2)}$, Philip G Crandall ${ }^{(3)}$, \\ Elizabeth M Martin ${ }^{(4)}$, Corliss A \\ O'Bryan ${ }^{(3)}$
}

\begin{abstract}
Sweetgum (Liquidambar styraciflua L.) is the only species of its genus in the Western hemisphere. The species is a relatively early successional species with wide seed dispersal, fast growth and is considered one of the most adaptable tree species in North America, growing across a wide range of soil types, altitudes, and hydrologic conditions. This species has routinely been considered a lesser desired species by many forest managers trying to grow tree plantations or even in natural stands because the species tends to rapidly invade and dominate a site. However, because of sweetgum's adaptability, ease of propagation and field planting, and fast growth rate, the tending of sweetgum as a potential crop for improved markets has been reinvigorated. Managing sweetgum also opens the possibility of development of new products and markets that supplement the traditional markets and can produce further value-added products. Increasingly, sweetgum is not viewed with as much antipathy amongst foresters and its potential as valuable resources is being rediscovered.
\end{abstract}

Keywords: Sweetgum, Liquidambar styraciflua L., Fast-growing species, Potential crop, Value-added products inhabitation of North America, probably moving into the continent during the existence of an ancient North Atlantic land bridge that predates the more commonly known North Pacific land bridge (Hoey \& Parks 1991). A relic of this ancient migration is also evident in modern genetic divergence data, in which sweetgum is actually a closer relative to the western Asia/Europe species, L. orientalis, than the two east Asian species, L. formosa and L. acalycina. The genetic identity based on a proportion of 22 loci similar between the two species is 0.51 . While it potentially maintained contact with the east Asian species via the North Pacific land bridge, the North American species had lower genetic identities of 0.43 and 0.48 with L. formosa and L. acalycina, respectively (Hoey \& Parks 1991, est genetic similarities were between the Europe/west Asia species and the two east Asia species (Hoey \& Parks 1991).

Though the species have been isolated 1994, Li et al. 1997). Interestingly, the low-

(1) School of Forestry, Louisiana Tech University, Ruston, Louisiana 71270 (USA); (2) Sea Star International LLC, Fayetteville, Arkansas 72701 (USA); (3) Departments of Food Science and Center for Food Safety, Fayetteville, Arkansas 72704 (USA); (4) Departments of Biological and Agricultural Engineering, University of Arkansas, Fayetteville, Arkansas 72704 (USA)

@ Joshua P Adams (adamsj@latech.edu)

Received: Oct 02, 2014 - Accepted: Apr 21, 2015

Citation: Adams JP, Lingbeck JM, Crandall PG, Martin EM, O'Bryan CA (2015). Sweetgum: a new look. iForest 8: 719-727. - doi: 10.3832/ifor1462-008 [online 2015-06-23]

Communicated by: Gianfranco Minotta for thousands of years, they are derived from a common ancestor in the Miocene era that favored sites of mesic, warm temperate areas (Hoey \& Parks 1991). The end of the Miocene saw global cooling and the beginning of glaciation in the Pleistocene epoch. These climatic changes limited the genetic exchange among the species progenitors and greatly limited each species geographical range on the landscape (Wolfe 1985). Though having a long period of separation, the species have similar morphologies thought to be due to evolutionary stasis and have similar ideal growing conditions (i.e., mesic and warm - Hoey \& Parks 1991).

The North American sweetgum has migrated significantly since becoming isolated from the other Liquidambar species but has maintained its preference for the same prehistoric growing conditions. In the last 20000 years of the late Quaternary period comprising the Holocene epoch, sweetgum has migrated in iterations from north to south with glacial movements (Williams et al. 2004). These glacial periods were at their maximum between 21000 and 14000 years ago pushing mesic, warm climate species like sweetgum to the far south including the extreme gulf coast, Florida, and Mesoamerica (Ruiz-Sanchez \& Ornelas 2014, Wright 1981). As glaciers began to recede and the climate warmed and became wetter, the suite of present day hardwood species began to move north again. Only in the last 3000 years did sweetgum appear to begin to dominate the southeast forests based on fossilized pollen samples (Williams et al. 2004). 


\section{Silvics, silviculture, and management overview}

\section{Silvics} Florida to eastern Texas. Its extreme northern range extends to Connecticut and southern Illinois, south to the Gulf of Mexico coast with scattered locations through central America (Kormanik 1990). In the past, the central American populations were classified as their own species, Liquidambar macrophylla (Orsted 1863); however, through the $20^{\text {th }}$ century there emerged a consensus in literature that the group should be lumped into $L$. styraciflua. The species is regarded as one of the most adaptable hardwood species in regards to site conditions, growing best on moist alluvial clays and loamy soils associated with river floodplains (Kormanik 1990). The species is a major component of four forest cover types, a minor component of over 20 others, and is commonly associated with other species such as maples (Acer rubrum and $A$. negundo), various hickories (Carya glabra, C. laciniosa, C. ovate, and C. tomentosa), and shortleaf and loblolly pine (Pinus echinata and $P$. taeda, respectively).

Sweetgum enters into these site associations via wind-blown seeds which are particularly adapted to wind dissemination through the presence of small winged structures on the seed. The seeds emerge after fruiting bodies mature by September through November. The seeds are small and prolific in which a kilogram of seed average 180000 seeds compared to the associated species $P$. taeda which may only average up to 40000 seeds $\mathrm{kg}^{-1}$ (Bonner \&
Presently, sweetgum grows from central

Karrfalt 2008). Germination of the seeds can occur quickly as they exhibit only a shallow dormancy (Nikolaeva 1969). Indeed with no cold stratification necessary, seeds may begin to germinate after an average of 7-8 days in a germinator and can reach $90 \%$ germination after only 11 days (Rink et al. 1979).

The initial growth traits can lead to rapid colonization of a site, and within various forest types, sweetgum is considered a shade intolerant species and grows very rapidly to reach sunlight (Meadows \& Stanturf 1997). On a site cleared of overstory, sweetgum will tend to dominate the site early and continue to be a major component in the early to mid-successional stages of a forest which can persist in southeastern U.S. forests for 200 years or longer (Hodges 1997). Cleared sites are also quickly re-colonized by sweetgum through prolific sprouting that produces vigorous and persistent new trees (Wenger 1953). On sites that are primarily regenerated with pine species, sweetgum is able to take the place of pines as the pine cohort begins to senesce as the stand goes through natural successional changes. Thus, sweetgum can become the dominant cover species until they are replaced by more shade-tolerant species (Hartnett \& Krofta 1989).

\section{Control of unwanted sweetgum}

Sweetgum can be considered a weed or nuisance tree in the context of some stand management objectives (Fig. 2). In a study on the Yazoo National Wildlife Refuge, sweetgum was the most common species into the area designated for cherrybark (Quercus pagoda), Nuttall (Q. nuttallii), Shu-

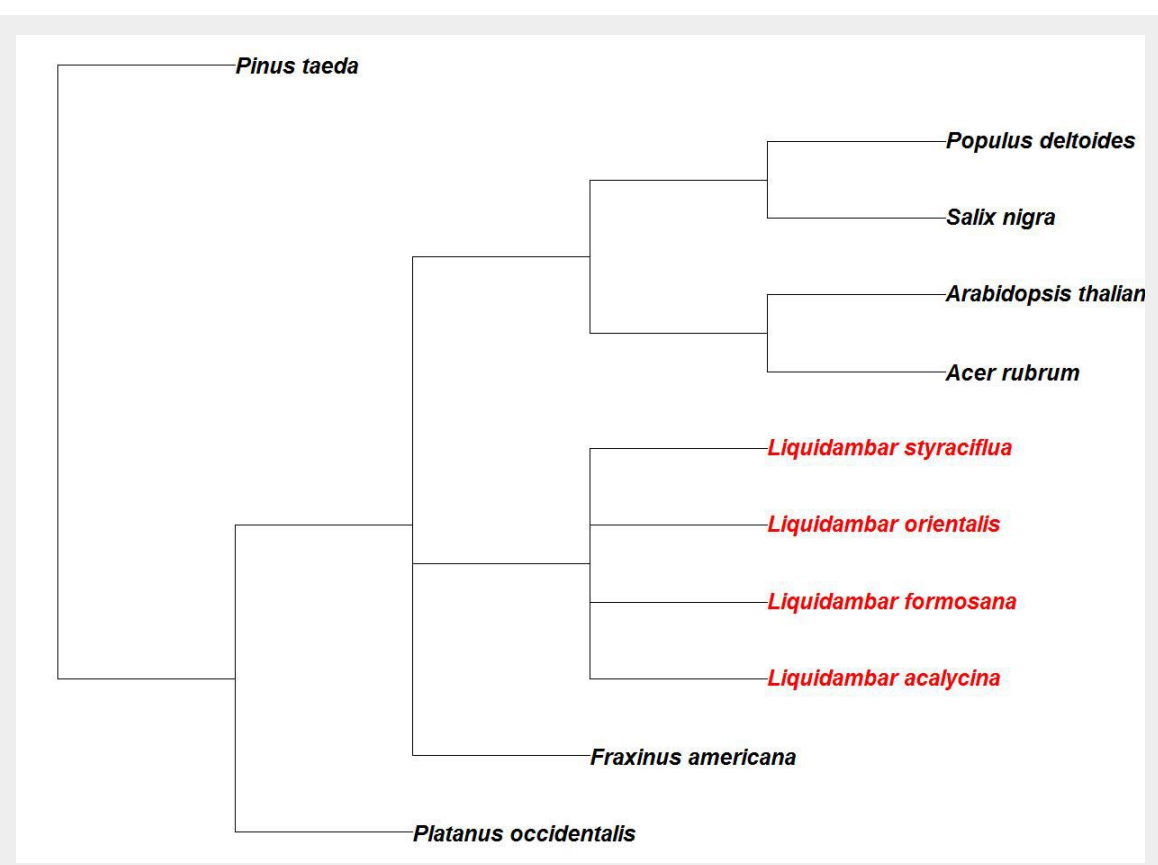

Fig. 1 - A dendrogram created from the NCBI taxonomy browser (http://www.ncbi. nlm.nih.gov/Taxonomy/taxonomyhome.html/index.cgi) using other tree species that are common to southeast United States' forests. Species of the Liquidambar genus are in red. mard (Q. shumardii), water (Q. nigra), and willow oak (Q. phellos) regeneration. This study led to the recommendation of planting additional oak seedlings to ensure these heavy-seeded species were present for wildlife management objectives (Allen 1990). During initiation of southern pine stands that dominate timber production in the southeast U.S., sweetgum is a definite concern. The presence of sweetgum can lead to greater competition for limited resources such as water, reducing survival and growth of the desired pine trees. Sweetgum can reduce soil moisture at depths of $60-90 \mathrm{~cm}$ in the soil which can directly adversely affect potential growth of the planted $P$. taeda stand (Mitchell et al. 1993). Especially during times of limited water which is common from June to September in much of the pine-sweetgum range, the effect of increased competition by sweetgum can lead to exacerbated water stress and changes in stomatal conductance, the exchange of carbon dioxide molecules through the leaf stomata, which affects photosynthesis (Perry et al. 1994).

Removal of sweetgum is often conducted during the initial stages of stand development. This allows desired species to establish and be more competitive with later incursions by sweetgum. Control of juvenile sweetgum can be conducted effectively through use of various herbicides such as glyphosate (e.g., Roundup ${ }^{\mathrm{TM}}$ ) which can be applied via aerial, tractor, ATV, or manual back pack sprayer depending on the site, size of area, and affordability. Indeed, non-specific, broadcast spraying of a site can be very effective in control of sweetgum. D'Anieri et al. (1990) reported that sweetgum translocated $48 \%$ of applied foliar glyphosate to roots in comparison to common associates $P$. taeda and Acer rubrum L., $3 \%$ and $13 \%$, respectively. Efficacy of glyphosate treatments is very good with $1.68 \mathrm{~kg} \mathrm{~m}^{-2}$ glyphosate application effectively controlling $64-93 \%$ of sweetgum after one year (Larsen et al. 1983, Wu et al. 1983). Bacon \& Zedaker (1987) found that removal of just two-thirds of woody competition (largely sweetgum) and herbaceous control could result in a $53 \%$ increase in loblolly pine stem volume growth in the second year. With only total woody control (no herbaceous control), there was still a $10 \%$ increase in pine volume production. Several other herbicides are notably effective at controlling sweetgum, including imazapyr, hexazinone, and triclopyr (Clatterbuck \& Armel 2011, Nelson et al. 2006). As for all herbicide treatments, the costs of the herbicides must then be carried for the length of the stand rotation (e.g., 25-35 years for an average managed loblolly pine stand), thus affecting decisions on sweetgum removal.

\section{Advances in propagation and growth}

While sweetgum may be regarded as of marginal value, current and potential product markets may make sweetgum more 
favorable in the future. Currently it is used as a component in natural forest stands in floodplain areas and as an ornamental in some landscaping plans. To propel sweetgum as a primary candidate for some of these uses, artificial propagation of sweetgum will be necessary to ensure that superior sweetgum trees are effectively and cheaply produced. Hare (1976) successfully propagated cuttings that were taken from mature sweetgum (species formosa and styraciflua) crowns. In early May, shoots were harvested and planted in a perlitevermiculite mixture with temperature and water control. After two months, up to $36 \%$ of cuttings rooted. Greater survival percentages are achievable by taking a more traditional approach and using cuttings from sprouts. Vegetative shoots from severely pruned $L$. styraciflua plants resulted in $86 \%$ of cuttings rooted and $56 \%$ of cuttings surviving and deemed plantable 25 weeks after the cutting was rooted (Rieckermann et al. 1999). Rieckermann et al. (1999) also found that a weekly nitrogen (N) application of $25-50 \mathrm{mg} \mathrm{l}^{-1}$ was optimal for promoting cutting development. Using severely pruned plants or hedging techniques, sweetgum can be quickly propagated. These mini-cutting techniques involve initial propagation of cuttings to produce mini-stumps that are hedged and produce successive integrations of sprouts (averaging about 2.5 sprouts per 30 days) used as micro-cuttings (Wendling et al. 2010). After 10 intervals of harvesting mini-cuttings, only $6 \%$ of the mini-stumps had died. This method was able to produce close to 3000 mini-cuttings per square meter per year and is a viable method to quickly expand germplasm for field plantings (Wendling et al. 2010).

Sweetgum has also been successfully propagated in vitro for many years. One of the earliest reports of an in vitro method was in 1980 using solid and liquid media (Sommer \& Brown 1980). The researchers based their initial work on established tobacco protocols and found that bud differentiation would occur with cytokinin/auxin ratios of (0.8-1.6 $\mathrm{mg} \mathrm{I}^{-1}$ benzyadenine (BA) and 0.1-1.0 $\mathrm{mg} \mathrm{|}^{-1}$ naphthaleneacetic acid (NAA), while root formation was conducted on media with a decreased ratio (0.2 $\mathrm{mg} \mathrm{l}^{-1}$ BA and 1.0-4.0 $\mathrm{mg} \mathrm{I}^{-1} \mathrm{NAA}$ ). Researchers germinated seedlings, excised the hypocotyl, and put sections of the tissue in the above cultures. Some cultures were transferred to the same mediums without agar (i.e., liquid state) and maintained in a shaker. In both solid and liquid form, successful somatic embryogenesis was achieved.

This early success was followed by mature and juvenile plants successfully propagated using excised shoot tips which were surface-sterilized with sodium hypochlorite (Sutter \& Barker 1985). Both mature and juvenile plants responded best when first placed in a multiplication media composed of Woody Plant Medium

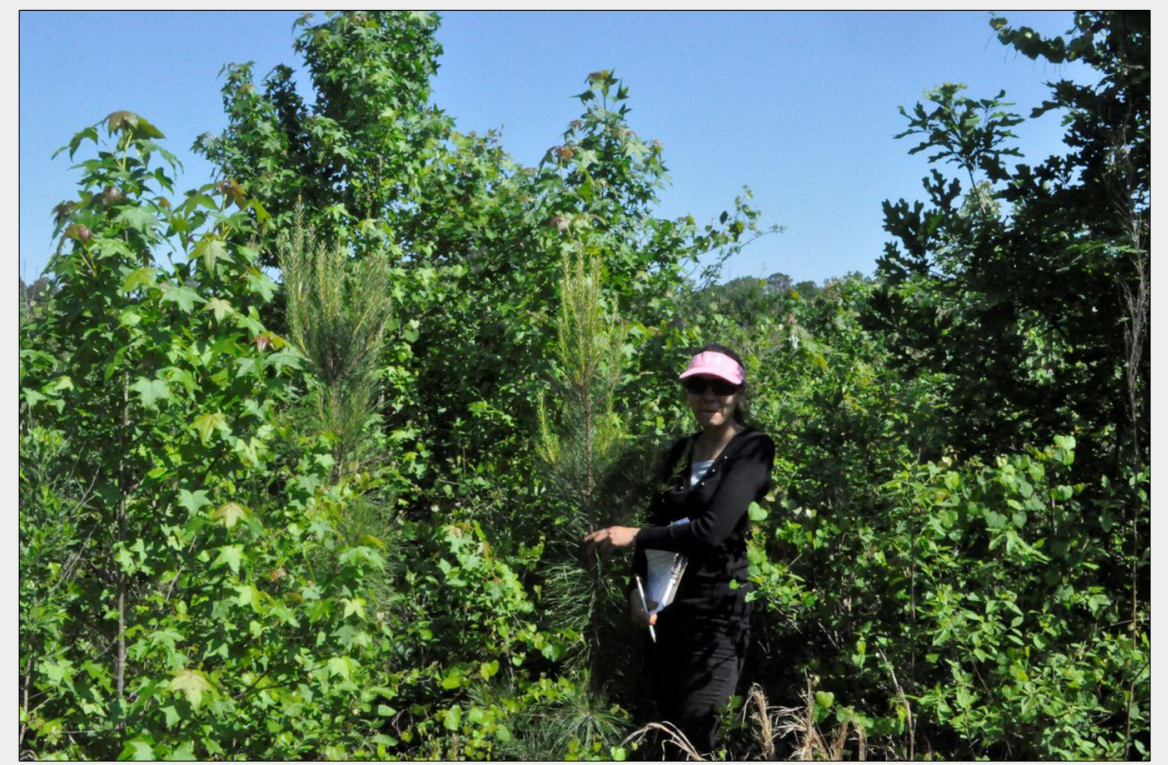

Fig. 2 - Graduate student holding a desirable three-year-old loblolly pine that is under intense competition from fast growing sweetgum that naturally seeded into the area after the pine was planted. Sweetgum can be seen in both the foreground and background and is already taller and crowding out the planted loblolly pine.

(WPM), basal salt supplemented with 0.2 $\mathrm{mg} \mathrm{l}^{-1} \mathrm{BA}$ and $0.05 \mathrm{mg} \mathrm{l}^{-1} \mathrm{NAA}$. Explants from successful multiplication were then rooted in WPM supplemented with $0.5-1.0 \mathrm{mg} \mathrm{I}^{-1}$ indole-3-butyric acid (IBA). While propagation was successful, large differences in rooting percentages (33-100\%) were evident among parent stock (Sutter \& Barker 1985).

A protocol using the same hormones was used by Brand \& Lineberger (1988) on leaf tissue. Woody Plant Medium (WPM) basal salt supplemented with $2.5 \mathrm{mg} \mathrm{l}^{-1} \mathrm{BA}$ and 0.1 $\mathrm{mg} \mathrm{l}^{-1} \mathrm{NAA}$ was used to elicit shoot formation from leaf tissue. Shoot formation was increased by damaging the leaf surface by cutting the lamina with razor. The authors found later in at least one variety, leaves used from intact plants produced over four times the amount of adventitious shoots than plants from in vitro use but was constant as the leaves aged (Brand \& Lineberger 1991). In conjunction with development of in vitro techniques for propagation, molecular transformation techniques have been developed which allow for the potential of production of genetically modified sweetgums. These could be engineered with advantageous traits such as superior growth, regulation of seed production, and modified chemical synthesis. Sullivan \& Lagrimini (1993) were able to transform sweetgum plantlets with three different plasmids via Agrobacterium tumefaciens infection. Leaves were excised and transversely cut at the midrib and incubated with the bacteria for three days in BA supplemented $2.5 \mathrm{mg} \mathrm{l}^{-1}$ BA WPM media. Afterwards, the bacterium was killed with cefotaxime and the leaf tissues were transferred to fresh media. Callus tissue initially formed followed by shoots which were excised and transferred to larger vessels. Plasmids have also been successfully transformed into sweetgum cultures via gold particle bombardment. Using established bombardment protocols, Kim et al. (1999) were able to generate nodule cultures which were receptive to the gene transfer treatment. They found that sweetgum nodules established from seedling hypocotyls should be proliferated using a liquid medium and had desirable traits including rapid growth of colonies, uniform cell size, and ability to produce regenerative tissue.

Sweetgum also appears to be easily transferred from in vitro to greenhouse and subsequent field conditions. In vitro plants were noted to have physiological abnormalities including limited cytoplasm content, large leaf vacuoles, decreased starch content, and increased photosynthetic rates (Lee et al. 1985, Wetzstein \& Sommer 1982). Plantlets must be acclimated to field conditions and allowed time for their morphology and cellular physiology to transform into normal field-grown conditions. Transferred to soil and hardening off is easily conducted by maintaining high-humidity by using a plastic bag covering on the plant (Wetzstein \& Sommer 1982). Using such a technique allows for acclimation after about four weeks. Brand \& Lineberger (1988) were also able to easily root and acclimate shoots produced from leaf tissue culture.

\section{Silviculture and management}

The next stage of sweetgum propagation would be to plant the newly propagated plants in nursery-like conditions for outplanting to true field conditions. Allowing the propagules to acclimate and develop roots is critical for eventual outplanting. 


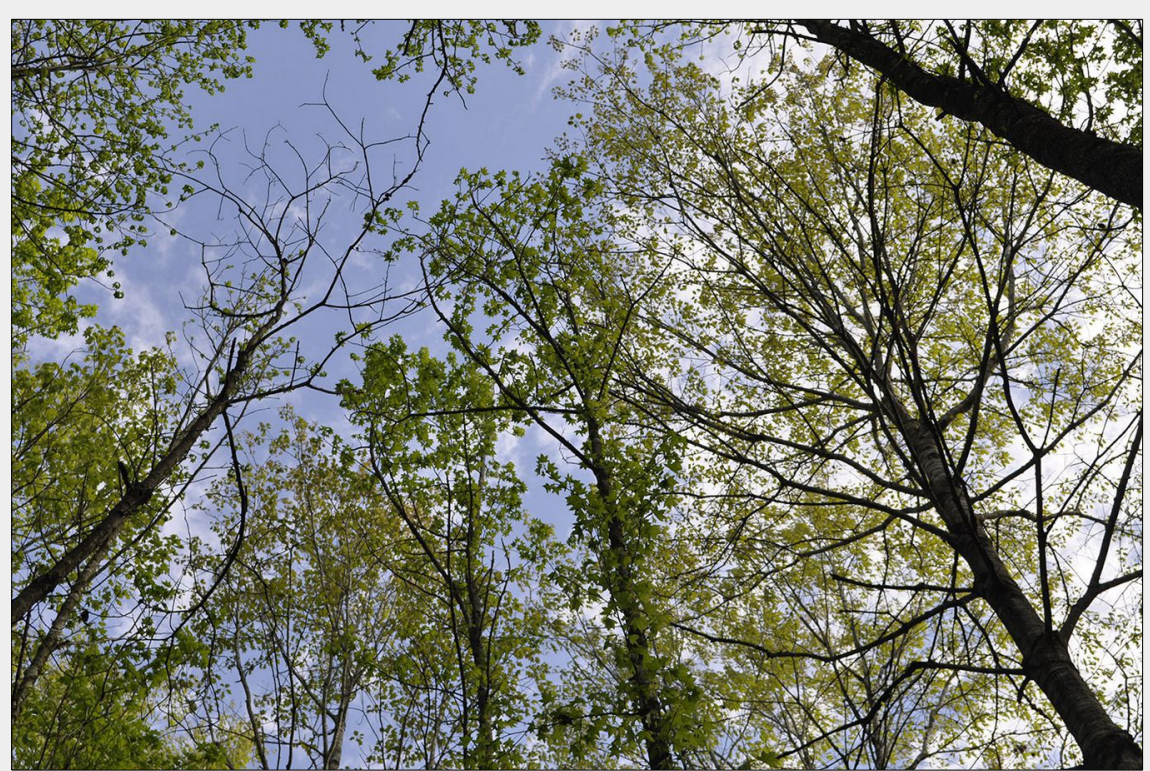

Fig. 3 - Sweetgum were planted and allowed to grow for 28 years around potentially more valuable cherrybark oaks. The crowns of sweetgum (narrow crowns in the center of the picture) are expected to help shear off limbs of the cherrybark oak, improving their quality. The sweetgum also serve as a source of income before the cherrybark oak is finally harvest which may be over 60 years.

Kormanik (1986) found that seedlings with more than six lateral roots exceeding $1 \mathrm{~mm}$ in diameter outperformed lower grade seedlings. These best seedlings only exhibited dieback in $41 \%$ of seedlings and had $79 \%$ survival after the first year; whereas, the two lower grades had $67 \%$ and $89 \%$ dieback and $67 \%$ and $51 \%$ survival after one year. Larger seedlings, in regards to root collar diameter (RCD), are also good indicators of later growth. Increases of RCD from 4-8 to $12-16 \mathrm{~mm}$ led to three-year increase in volume of $90 \%$ (Mc Nabb \& VanderSchaaf 2005).

During the seedling time ex vitro, the roots also have the added benefit of being exposed to beneficial mycorrhizal. These fungal infections resulted in $80 x$ greater above ground biomass after the seedling were grown for one year in nursery conditions (Bryan \& Kormanik 1977). Indeed, without mycorrhizal presence, seedlings are ill adapted to the competitive field environment and the plants will either die or be severely stunted (Kormanik et al. 1977). With mycorrhizal, sweetgum performs well with $\mathrm{N}$ fertilization $(560 \mathrm{~kg} \mathrm{~N}$ $\left.\mathrm{ha}^{-1}\right)$ in nursery conditions. Additionally, a fertilizer, such as ammonium nitrate, is preferable over ammonium sulfate, as it does not acidify the soil as severely (Brown et al. 1981).

Once deployed in plantations, established sweetgum thrives with fertilization. Through most of sweetgum's range, $N$ is one of the most limiting factors to growth in forest ecosystems and $\mathrm{N}$ additions consistently result in increased stand net primary production and increased fine root production (Chang 2003, Norby \& Iversen 2006, Iversen \& Norby 2008). In a young 4- year-old study sweetgum plantation, Guo et al. (1998) applied $\mathrm{N}$ and phosphorous (P) treatments and found that a N+P (229.8 $\mathrm{kg} \mathrm{ha}^{-1}$ and $137.9 \mathrm{~kg} \mathrm{ha}^{-1}$, respectively) combination treatment or $\mathrm{N}$ alone treatment at $229.8 \mathrm{~kg} \mathrm{ha}^{-1}$ generally performed the best in regards to tree height, diameter and crown length. These effects were very evident after the first year-post treatment (i.e., ages 6 and above) and were maintained through the course of the study when the stand was 15-years-old. In a 9-year-old plantation, sweetgum produced the most aboveground biomass at highest fertilization levels in the study that were equivalent of $400 \mathrm{~kg} \mathrm{~N} \mathrm{ha}^{-1}$ (Nelson et al. 1995); however, annual incremental growth is measurable for only one to two years ( $\mathrm{Nel}$ son \& Switzer 1990). Still, the need for fertilization is site specific and each site should be tested for its inherent nutrients. Scott et al. (2004) found that on a converted agriculture field rich in nutrients, there was no effect on sweetgum growth from the addition of $\mathrm{N}$ and $\mathrm{P}$, while trees on a forest cut-over site responded with a $60 \%$ increase in biomass.

Deployment of whole plantations of sweetgum can generate rapid biomass production which can be used for many of the outlined products. Volume production ranged from $8.4 \mathrm{~m}^{3} \mathrm{ha}^{-1}$ year ${ }^{-1}$ to $18.62 \mathrm{~m}^{3} \mathrm{ha}^{-1}$ year ${ }^{-1}$ with no fertilizer up to $399 \mathrm{~kg} \mathrm{ha}^{-1}$ in a Mississippi study after nine years (Nelson \& Switzer 1992). In the same study, increases in dimensional attributes after nine years were $9,14,28,39$, and $40 \%$ for height, DBH, basal area, stem volume, and woody biomass, respectively (Nelson \& Switzer 1990). In South Carolina with irrigation and fertilization four-year growth rates of sweetgum ranged from 2.4 to $5.1 \mathrm{Mg}$ ha $^{-1}$ year $^{-1}$ (Coyle et al. 2008). On a marginal agriculture site in Georgia, sweetgum grown without any amendments produced average of $12.3 \mathrm{Mg} \mathrm{ha}^{-1}$ after six years, while maximal amendments (irrigation+fertilization+pest control) resulted in $62.6 \mathrm{Mg} \mathrm{ha}^{-1}$.

While sweetgum is capable for producing rapid growth suitable for short rotation crops, sweetgum is a valued hardwood lumber species. As such, there is renewed interest in sweetgum as a valuable component to predominantly oak stands by exploiting its natural place in river floodplain ecosystems. In an attempt to mimic natural stand succession, Lockhart et al. (2006) planted cherrybark oak (Quercus pagoda) and sweetgum seedlings in mixtures. In these mixtures, cherrybark oak seedlings were surrounded by two rows of sweetgum (Fig. 3). Initially the stand was dominated by sweetgum as would be expected based on its early and aggressive growth. After 21 years, the sweetgum began to stagnate and the cherrybark oak ascended into the upper canopy. This planned species succession offers potential benefits of a harvest of sweetgum timber before the cherrybark oaks are harvested which can be $60-80$ years in some cases. While cherrybark oaks are competing with sweetgum for light, the sweetgum serves as a "trainer" tree to increase the bole quality of cherrybark oak. This echoes an earlier study by Clatterbuck \& Hodges (1988) which found a lack of different species like sweetgum around the desirable cherrybark oak trees caused the cherrybark oak to have poor form (e.g., many branches, straightness deficiencies) and to be commercially less desirable.

Mid-rotation removal of sweetgum is warranted. Johnson \& Krinard (1988) found that in a two mixed sweetgum-red oak stands (red oaks were composed of $Q$. pagoda, Q. phellos and Q. nigra), approximately $25 \%$ of the sweetgum trees died between ages 18 and 23. This was immediately following the maximum observed density (3879 trees per hectare) on the site at which time light became a limiting factor. This increased competition and decline in sweetgum led to the red oak trees growing twice as fast in diameter and 60\% faster in height between ages 23 and 29. The growth changes led to the prediction of oaks overtaking the sweetgum in total height by ages 30 to 35 . Similar trends were all observed by Clatterbuck et al. (1984), who found that oaks in their old field stand overtook sweetgum as early as age 15 to 25 years.

A final regeneration harvest necessitates a system that lead to maximal light interception for sweetgum. A clearcut method is optimal for even-age regeneration of a stand. This system will favor in the early years of regeneration shade-intolerant and light-seeded species such as sweetgum and river birch (Meadows \& Stanturf 1997). A seed-tree method would also have the 
same effect, while leaving trees on site may be a waste as the species is so light seeded that blown in seed from adjacent areas or regeneration from root sprouts is usually assured (Meadows \& Stanturf 1997). The shelterwood system as well as the uneven-age system, single-tree selection, are usually not favored for final harvest if the goal is sweetgum regeneration as they favor more shade tolerant species such as elms and maples (Johnson \& Krinard 1983). Indeed, even the uneven-age system group selection usually does not produce openings in the canopy large enough to maintain a shade intolerant species such as sweetgum (Clatterbuck \& Meadows 1993). Thus final harvest options, with the intent of sweetgum regeneration, are very limited.

\section{Commercial products}

\section{Early uses}

Sweetgum has chemical properties that are beneficial for a large array of ailments as detailed by Lingbeck et al. (2015). These benefits have been harnessed from early times with several Native American tribes documented as using sweetgum for medicinal purposes. Hamel \& Chiltoskey (1975) documented several uses among the Cherokee tribe including using rosin and inner bark for diarrhea, flux, and dysentery, salve from leaves used for wounds, sores, and ulcers, and infusions of bark were used as a sedative and given to people with nervousness. The Choctaw and Houma tribes of Louisiana both used a root mixture for dressing cuts and wounds (Bushnell 1909, Speck 1941). These tribes also used the solidified sap as chewing gum. This practice may even continue today and certainly was prevalent during the early $20^{\text {th }}$ century based on personal communications with several people from Louisiana born during the great depression.

Many of these same uses of sweetgum were kept after European colonization. During the civil war, a field guide for medical officers was commissioned for the Confederate States and published after the war. Sweetgum was mentioned many times in this book (Porcher 1869). In the guide, the author mentions many of the same uses for patients including boiling equal amounts of red oak and sweetgum into syrup, adding spirits, and digesting the concoction to alleviate diarrhea and dysentery. The manual also recommend mixing the extract with tea or water. Ironically, water extraction is successfully used in current times to extract shikimic acid from sweetgum bark as a precursor to Tamiflu ${ }^{\circledR}$ (Martin et al. 2010). The leaves of the sweetgum were said to contain high tannin levels to provide a powerful astringent. One interesting comment in the guide is a reference to an acid obtained from sweetgum. The author states that he disagrees with the English assentation that benzoic acid is prevalent but rather cynamic acid.

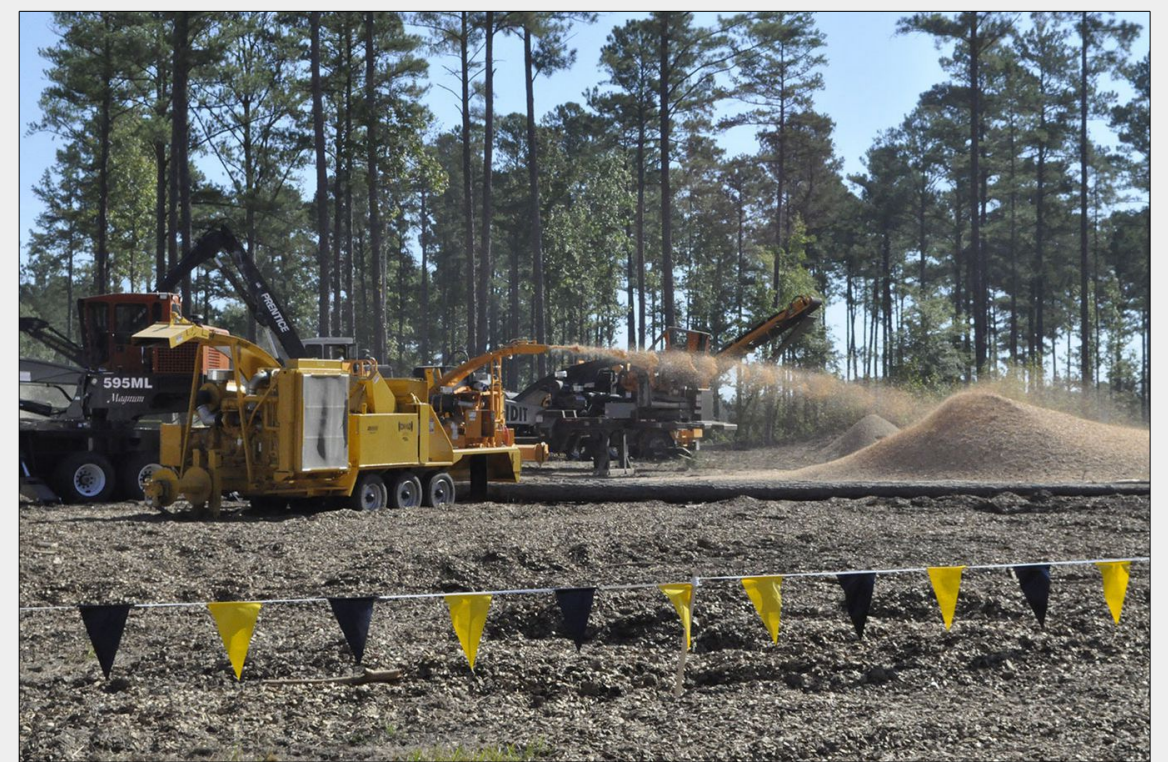

Fig. 4 - An industrial chipper is being used by a logging crew to produce chips from sweetgum and other hardwoods in a pine plantation. Chips are able to be used as a source of biomass fuel.

This early reference to "cynamic acid" is probably the same cinnamic acid that has since been more recently "rediscovered" and studied across the Liquidambar species for its antioxidant, antipathogenic, and antimicrobial properties (Karadeniz et al. 2011, Ocsel et al. 2012, Sova 2012, Gurbuz et al. 2013).

\section{Timber}

While much emphasis has dealt with the removal of sweetgum from future timber streams, sweetgum can be utilized for pulp, furniture grade lumber, pallets, veneer and panels. The heartwood of the sweetgum trees is reddish brown with interlocking grain and is often mistaken for cherry wood, given rise to the species also being called redgum. The red heartwood was often used in furniture, millwork, doors and paneling, and was once a valuable resource as it was sold in European markets as satin walnut (Cassens 2007). Dwindling supplies of the old-growth red heartwood, however, led to an increase in sapwood use. Today, most sweetgum lumber is from the sapwood which is white in color with a pinkish tint (Cassens 2007). Sapwood is used in making low end furniture and furniture frames. However, development of composite wood for this purpose has reduced the demand for sweetgum lumber. Due to its high shrinkage coefficient and its tendency to warp due to its interlocked grain, sweetgum wood is one of the lowest valued hardwoods available (Cassens 2007). Still, sweetgum has wood properties that make it amenable to modern wood processing techniques. The species is easily peeled into veneers for use in plywood which can have at least equal strength compared to similar processed southern pine plywood (Biblis \& Lee 1984).
Recent lamination developments in structural lumber have opened other uses for sweetgum which can be oriented to create beams of considerable strength and light weight for construction of bridges and ground flotation mats on which heavy equipment is placed to prevent soil disturbance (Shmulsky et al. 2008, Shmulsky \& Shi 2008).

\section{Biomass}

Biomass is a term for organic material from plants and may be a key source of renewable energy, possibly replacing or reducing our demand for supplies of fossil fuels (Wang et al. 2012). The ability of sweetgum to rapidly grow on a wide range of soils, as well as its ability to re-sprout ble biomass source to be used for bioenergy production including cellulosic ethanol, wood pellets and bio-oil (Wright \& Cunningham 2008). This rapid proliferation of products could be tied with recent advances in development of specific varieties produced through tissue culture that are promising for short-rotation biomass (Merkle \& Cunningham 2011). The cultures would be grown for just a few years and then harvested and chipped before refined into a specific product (Fig. 4). However, hardwood plantations of sweetgum may not be economically viable. In 2006, estimated costs for production of a sweetgum plantation throughout the first 12 years range from 778 to 1742 US\$ per hectare including costs associated with site preparation, planting, herbicide and pesticide treatments and fertilization. For a low producing plantation ( $5 \mathrm{Mg}$ per hectare per year) that could result in costs of 31 to 64 US\$ per Mg. Higher producing sweetgum plantations could expect costs of 13 to 27 prolifically, make sweetgum trees a suita- 
US\$ per Mg compared to rival species eastern cottonwood and pine which could cost 14-40 and 6-18 US\$, respectively, in highly productive plantations (Kline \& Coleman 2010). When costs of logging and transportation are factored in, only high producing plantations could expect to yield a profit given a target delivery price of 55 US\$ per Mg (DOE 2007, Kline \& Coleman 2010).

\section{Cellulosic ethanol}

The generation of ethanol from cellulosic biomass offers many benefits. Ethanol is cleaner burning that traditional fuels, thus reducing pollution and greenhouse emissions which may lead to global warming (Wyman et al. 1992). Perhaps the biggest benefit of cellulosic ethanol is the utilization of abundant, low-cost feedstocks which may otherwise be considered waste. Cellulosic ethanol is generated from enzymatic hydrolysis of cellulose to form glucose which is then fermented to produce ethanol. However, due to the lignin content, which protects much of the cellulose from enzymatic action, a pretreatment step before hydrolysis is usually necessary to increases yields. Common pretreatment steps include treatment with dilute acid or base, hot water, an organic solvent (organoslov) or by steam explosion (Yang \& Wyman 2008, Zhao et al. 2009).

Wyman et al. (1992) studied the efficiency of simultaneous saccharification and fermentation (SSF) method in which biomass, hydrolysis enzymes and fermentation yeast are added together in one vessel. Greater ethanol yields are often seen with SSF because sugars, which are inhibitory to the conversion process, are rapidly converted to ethanol. Four woody crops (aspen, two hybrids poplars and sweetgum), three herbaceous crops (switchgrass, weeping love grass and a legume Sericea lespedeza) and three agricultural residues (corn cobs, corn stover and wheat straw) were studied. The biomass was pretreated in dilute acid and woody crops were ground before they were placed in the fermentation flask containing supplemented media along with cellulase, $\beta$-glucosidase (to reduce accumulation of the inhibitor cellobiose) and the yeast $S$. cerevisiae alone or in a mixed culture with $\mathrm{B}$. clausenii and incubated at $37^{\circ} \mathrm{C}$ for 8 days. With $S$. cerevisiae alone, the agricultural residues, corn cobs, corn stover and wheat straw produced the highest cellulose to ethanol conversion of 94, 92 and $90 \%$, respectively. The herbaceous crops, weeping love grass and switch grass, produced $89 \%$ and $84 \%$, respectively, while Sericea lespedeza showed poor yields of $52 \%$. The woody crops Populus maximowiczii $x$ nigra, Populus trichocarpa $\times$ deltoides, Populus tremuloides (aspen) and sweetgum produced 90, 82, 94, and $86 \%$ yields, respectively. Results were similar with mixed yeast cultures at high enzyme and $\beta$-glucosidase concentrations. Using a similar protocol of pentose fermentation, the costs of hardwood produced ethanol was estimated to be about 0.61 US\$ $\mathrm{L}^{-1}$ with the main costs attributable to raw materials and capital (Sassner et al. 2008).

McConnell \& Shi (2011) evaluated the partial hydrolysis of dilute sulfuric acid, dilute sodium hydroxide and deionized water on holocellulose content (total polysaccharides fraction from wood) from sweetgum, red oak and yellow-poplar (Liriodendron tulipifera). All treatments reduced holocellulose levels in all species; however, sulfuric acid treatment showed the greatest reduction in holocellulose levels in sweetgum and red oak, while sodium hydroxide showed the greatest reduction of holocellulose levels in yellow-poplar. In addition, partial hydrolysis with dilute sulfuric acid of sweetgum and red oak produced residual properties in the wood which may make them suitable for use in wood composites adding additional value to the lignocellulosic ethanol production process (McConnell \& Shi 2011).

Sannigrahi et al. (2012) used a two-step ozone pretreatment to increase polysaccharide release and hence increase ethanol production from sweetgum and miscanthus. In the first step, the biomass was treated with ozone gas to generate acidic components. The biomass was then equilibrated in water and subject to autohydrolysis at high temperature and pressure to increase solubilization of celluloses. The resultant cellulose was converted glucose at a conversion rate of $68 \%$ for both sweetgum and miscanthus. The glucose was finally fermented to produce ethanol with yields of $14.0 \mathrm{~g}$ ethanol per $100 \mathrm{~g}$ biomass for sweetgum and miscanthus was $11.1 \mathrm{~g}$ ethanol per $100 \mathrm{~g}$ biomass. In addition, ozone pretreatment is relatively inexpensive and generates an environmentally friendly waste stream and is thus a promising pretreatment strategy (Sannigrahi et al. 2012).

\section{Bio-oil}

Bio-oil is generated from the fast pyrolysis of biomass and has the potential to be used as liquid fuel (Bridgwater et al. 2002). Sweetgum, switchgrass and corn stover were all evaluated for their ability to produce bio-oil after various pretreatments. Sweetgum, with particle sizes from 0.68 to $1.532 \mathrm{~mm}$ produced $52 \mathrm{wt} \%$ of bio-oil from fast pyrolysis in which the biomass was rapidly heated from $350-600{ }^{\circ} \mathrm{C}$ in the absence of oxygen. In comparison, similar sized switchgrass produced 33 wt\% while corn stover produced $35 \mathrm{wt} \%$. Steam explosion pre-treatment lower bio-oil yield for all three biomass compound pre-treatment with $1 \%$ sulfuric acid increase yields to $56 \%$, $46 \%$ and $51 \%$ for sweetgum, switchgrass and corn stover, respectively. The reduced yield seen with steam explosion was thought to be due to the reduction of hemicellulose content after treatment, whereas pre-treatment with $1 \%$ acid increase yield due to reduced ash content which is thought to limit bio-oil production. The high rate of bio-oil production, along with the low cost of acid pretreatment and availability of sweetgum trees, make it feasible that sweetgum can be a source of biomass for bio-oil production (Wang et al. 2012).

\section{Economic assessment}

In the current era, most timber is sold by tonnage, segregated only by hardwood and pine with the exception of trees targeted for very specific, high-value uses (e.g., black walnut for high quality furniture and paneling or sycamore/cottonwood plantations used for specialty paper). In this common scenario of timber sales, logged hardwoods are combined and weighed in mass as either sawtimber or pulpwood, depending on the size of the tree $(\geq 30.5$ and $<30.5 \mathrm{~cm}$ diameter at breast height, respectively). Over an 11 state region stretching from Texas in the west to the Atlantic and as north as Virginia, the prices of mixed hardwood pulpwood surpassed pine pulpwood in 2010 (in many cases the highest stumpage prices ever received for such products) with an average $1^{\text {st }}$ quarter 2010 price of 11.05 US\$ tonne-1. Hardwood sawtimber has historically garnered higher prices with an average of 20.40 US\$ tonne ${ }^{-1}$ (TMS 2010). Since then, prices fell slightly and have slowly rebounded to near 2010 levels in early 2014 with pulpwood averaging 9.15 US\$ tonne ${ }^{-1}$ and sawtimber averaging 24.77 US\$ tonne (http://www.timbermart-south.com/ - TMS 2014). As it is so often lumped together with other hardwoods, sweetgum has garnered little specific study even from an economic prospective as prices have risen. For instance, the hardwood pricing publication Harwood Review Global (http://www. hardwoodreview.com) has costs broken down for a variety of species including cottonwood, cherry, hard maple, hickory, red oak, white oak, and walnut. However, sweetgum is noticeably lacking.

\section{Conclusion}

Sweetgum is a unique species in North America and has been separated from it relatives for many thousands of years. In its current ecosystem spanning over much of the eastern United States and into Central America, the species thrives. The species rapid growth rate and adaptability on many sites poises both promise and problems for forest management. When hardwood markets were weak, the species was considered by many a weed among the desirable species. More recently with the increased market for hardwood lumber and newer markets such as various biobased energy products, renewed interest is upon sweetgum. Instead of spending capital to rid sites of the native species, finding new methods to potentially harness value from the prolific species is now attractive.

The fast growth rate and developed culture systems make this species a prime 
candidate for use alone or with species mixtures for plantations. Systems of propagation have been developed that allow growers to totally capture any genetic trait deemed desirable and potentially massproduce for planting. After planting, sweetgum competes well with other species and, with some treatment such as fertilization or irrigation, accumulates large quantities of biomass. Other exciting aspects of this species are the medicinal properties that have been recently outlined by Lingbeck et al. (2015). Efficiently using the tree for both more traditional markets and integrating into developing markets such as biofuel and pharmaceuticals could propel the species to a more desirable status among the forest managers.

\section{References}

Allen JA (1990). Establishment of bottomland oak plantations on the Yazoo National Wildlife Refuge Complex. Southern Journal of Applied Forestry 14 (4): 206-210. [online] URL: http:// www.ingentaconnect.com/content/saf/sjaf/199 o/00000014/00000004/arto0013

Bacon CG, Zedaker SM (1987). Third-year growth response of loblolly pine to eight levels of competition control. Southern Journal of Applied Forestry 11 (2): 91-95. [online] URL: http:// www.ingentaconnect.com/content/saf/sjaf/198 7/000000011/00000002/art00008

Biblis EJ, Lee W-C (1984). Properties of sheathing-grade plywood made from sweetgum and southern pine. Wood and Fiber Science 16 (1): 86-92.

Bonner FT, Karrfalt RP (2008). The woody plant seed manual. Agriculture Handbook 727, USDA Forest Service, Washington, DC, USA, pp. 1223. [online] URL: http://books.google.com/books? id=ZnBRmdUU_zUC

Brand MH, Lineberger RD (1988). In vitro adventitious shoot formation on mature-phase leaves and petioles of Liquidambar styraciflua L. Plant Science 57 (2): 173-179. - doi: 10.1016/0168-9452 (88) $90084-2$

Brand MH, Lineberger RD (1991). The effect of leaf source and developmental stage on shoot organogenic potential of sweetgum (Liquidambar styraciflua L.) leaf explants. Plant Cell, Tissue and Organ Culture 24 (1): 1-7. - doi: 10.1007| BFooo 44257

Bridgwater A, Toft A, Brammer J (2002). A techno-economic comparison of power production by biomass fast pyrolysis with gasification and combustion. Renewable and Sustainable Energy Reviews 6 (3): 181-246. - doi: 10.1016/S13640321(01)00010-7

Brown R, Schultz R, Kormanik P (1981). Response of vesicular-arbuscular endomycorrhizal sweetgum seedlings to three nitrogen fertilizers. Forest Science 27 (2): 413-420. [online] URL: http://www.ingentaconnect.com/content/ saf/fs/1981/00000027/00000002/art00035

Bryan WC, Kormanik PP (1977). Mycorrhizae benefit survival and growth of sweetgum seedlings in the nursery. Southern Journal of Applied Forestry 1 (1): 21-23. [online] URL: http://www. ingentaconnect.com/content/saf/sjaf/1977/000 00001/00000001/art00009

Bushnell DI (1909). Choctaw of Bayou Lacomb,
St. Tammany Parish, Louisiana. Washington Government Printing Office, Washington, DC, USA, pp. 23.

Cassens DL (2007). Hardwood lumber and veneer series: sweetgum. Extension Publication FNR-300-W, Purdue University, West Lafayette, IN, USA, pp. 4. [online] URL: http://www.exten sion.purdue.edu/extmedia/FNR/FNR-300-W.pdf Chang SX (2003). Seedling sweetgum (Liquidambar styraciflua L.) half-sib family response to $\mathrm{N}$ and $\mathrm{P}$ fertilization: growth, leaf area, net photosynthesis and nutrient uptake. Forest Ecology and Management 173 (1-3): 281-291. - doi: 10.1016/S0378-1127(02)00007-5

Clatterbuck WK, Hodges JD, Burkhardt EC (1984). Cherrybark oak development in natural mixed oak-sweetgum stands - preliminary results. In: Proceedings of the " 3 rd Biennial Southern Silvicultural Research Conference" (Shoulders $\mathrm{E}$ ed). Southern Forest Experiment Station, USDA Forest Service, Atlanta, GA, USA, pp. 438-444.

Clatterbuck WK, Hodges JD (1988). Development of cherrybark oak and sweet gum in mixed, even-aged bottomland stands in central Mississippi, USA. Canadian Journal of Forest Research 18 (1): 12-18. - doi: 10.1139/x88-003

Clatterbuck W, Meadows J (1993). Regenerating oaks in the bottomlands. In: Proceedings of the Symposium "Oak Regeneration: Serious Problems, Practical Recommendations" (Loftis DL, McGee CE eds). Knoxville (TX, USA) 8-10 Sep 1992. General Technical Report SE-84, Southeastern Forest Experiment Station, USDA Forest Service, Asheville, NC, pp. 184-195.

Clatterbuck WK, Armel GR (2011). PB1799 site preparation for natural regeneration of hardwoods. Publication no. PB1799, University of Tennessee Extension, Knoxville, TX, USA, pp. 11. [online] URL: http://trace.tennessee.edu/utk_ agexfores/113

Coyle DR, Coleman MD, Aubrey DP (2008). Above-and below-ground biomass accumulation, production, and distribution of sweetgum and loblolly pine grown with irrigation and fertilization. Canadian Journal of Forest Research 38 (6): 1335-1348. - doi: 10.1139/X07-231

D'Anieri P, Zedaker SM, Seiler JR, Kreh RE (1990). Glyphosate translocation and efficacy relationships in red maple, sweetgum, and loblolly pine seedlings. Forest Science 36 (2): 438-447. [online] URL: http://www.ingentacon nect.com/content/saf/fs/1990/00000036/00000 $002 / a r t 00021$

DOE (2007). Biomass multi-year program plan. Office of the Biomass Program, Energy Efficiency and Renewable Energy, US Department of Energy, Washington, DC, USA.

Guo Y, Lockhart BR, Ka TT (1998). Effect of nitrogen and phosphorus fertilization on growth in a sweetgum plantation in southeastern Arkansas. Southern Journal of Applied Forestry 22 (3): 163-168. [online] URL: http://www.ingenta connect.com/content/saf/sjaf/1998/00000022/0 $0000003 /$ arto0008

Gurbuz I, Yesilada E, Demirci B, Sezik E, Demirci F, Baser KH (2013). Characterization of volatiles and anti-ulcerogenic effect of Turkish sweetgum balsam (Styrax liquidus). Journal of Ethnopharmacology 148 (1): 332-336. - doi: 10.1016/j. jep.2013.03.071
Hamel PB, Chiltoskey MU (1975). Cherokee plants and their uses - a 400 year history. Herald Publishing Co., Sylva, NC, USA, pp. 64.

Hare R (1976). Rooting of American and Formosan sweetgum cuttings taken from girdled and nongirdled cuttings. Tree Planters' Notes 27 (4): 6-7.

Hartnett DC, Krofta DM (1989). Fifty-five years of post-fire succession in a southern mixed hardwood forest. Bulletin of the Torrey Botanical Club 116 (2): 107-113. - doi: 10.2307/2997194

Hodges JD (1997). Development and ecology of bottomland hardwood sites. Forest Ecology and Management 90 (2-3): 117-125. - doi: 10.1016/S0378-1127(96)03906-0

Hoey MT, Parks CR (1991). Isozyme divergence between eastern Asian, North American, and Turkish species of Liquidambar (Hamamelidaceae). American Journal of Botany 78 (7): 938947. - doi: 10.2307/2445172

Hoey MT, Parks CR (1994). Genetic divergence in Liquidambar styraciflua, L. formosana, and L. acalycina (Hamamelidaceae). Systematic Botany 19 (2): 308-316. - doi: 10.2307/2419604 Iversen CM, Norby RJ (2008). Nitrogen limitation in a sweetgum plantation: implications for carbon allocation and storage. Canadian Journal of Forest Research 38 (5): 1021-1032. - doi: 10.1139/X07-213

Johnson RL, Krinard R (1983). Regeneration in small and large sawtimber sweetgum-red oak stands following selection and seed tree harvest: 23-year results. Southern Journal of Applied Forestry 7 (4): 176-184. [online] URL: http://www.ingentaconnect.com/content/saf/sj af/1983/00000007/000000004/art00003

Johnson RL, Krinard RM (1988). Growth and development of two sweetgum-red oak stands from origin through 29 years. Southern Journal of Applied Forestry 12 (2): 73-78. [online] URL: http://www.ingentaconnect.com/content/saf/sj af/1988/00000012/00000002/art00004

Karadeniz B, Ulker Z, Alpsoy L (2011). Genotoxic and cytotoxic effects of storax in vitro. Toxicology and Industrial Health 29 (2): 181-186. - doi: 10.1177/0748233711428642

Kim M, Sommer H, Dean JD, Merkle S (1999). Transformation of sweetgum via microprojectile bombardment of nodule cultures. In Vitro Cellular and Developmental Biology - Plant 35 (1): 37-42. - doi: 10.1007/s11627-999-0007-z

Kline KL, Coleman MD (2010). Woody energy crops in the southeastern United States: two centuries of practitioner experience. Biomass and Bioenergy 34 (12): 1655-1666. - doi: 10.1016/ j.biombioe.2010.05.005

Kormanik PP (1986). Lateral root morphology as an expression of sweetgum seedling quality. Forest Science 32 (3): 595-604. [online] URL: http://www.ingentaconnect.com/content/saf/fs /1986/00000032/00000003/art00008

Kormanik PP (1990). Liquidambar styraciflua L. sweetgum. In: "Silvics of North America - Vol. 2, Hardwoods" (Burns RM, Honkala BH eds). Agriculture Handbook 654, USDA Forest Service, Washington, DC, USA, pp. 400-405. [online] URL: http://books.google.com/books?id=bMnR qCA3uzwC

Kormanik PP, Bryan WC, Schultz RC (1977). Influence of endomycorrhizae on growth of sweetgum seedlings from eight mother trees. Forest 
Science 23 (4): 500-505. [online] URL: http:// www.ingentaconnect.com/content/saf/fs/1977/ $00000023 / 000000004 /$ arto0021

Kuprianova LA (1960). Palynological data contributing to the history of Liquidambar. Pollen et Spores 2 (1): 71-88.

Larsen T, Gnegy J, Olinger H (1983). Glyphosate for release of loblolly pine (Pinus taeda, hardwood competition). Proceedings of the Southern Weed Science Society 36: 235-238.

Lee N, Wetzstein HY, Sommer HE (1985). Effects of quantum flux density on photosynthesis and chloroplast ultrastructure in tissue-cultured plantlets and seedlings of Liquidambar styraciflua L. towards improved acclimatization and field survival. Plant Physiology 78 (3): 637-641. doi: 10.1104/pp.78.3.637

Li JH, Bogle AL, Klein AS (1997). Interspecific relationships and genetic divergence of the disjunct genus Liquidambar (Hamamelidaceae) inferred from DNA sequences of plastid gene matK. Rhodora 99 (899): 229-240.

Lingbeck JM, O'Bryan CA, Martin EM, Adams JP, Crandall PG (2015). Sweetgum: an ancient source of beneficial compounds with modern benefits. Pharmcognosy Review 9 (17) 1-11. - doi: 10.4103/0973-7847.156307

Lockhart BR, Ezell AW, Hodges JD, Clatterbuck WK (2006). Using natural stand development patterns in artificial mixtures: a case study with cherrybark oak and sweetgum in east-central Mississippi, USA. Forest Ecology and Management 222 (1): 202-210. - doi: 10.1016/j.foreco.20 05.09 .029

Martin E, Duke J, Pelkki M, Clausen E, Carrier D (2010). Sweetgum (Liquidambar styraciflua L.): extraction of shikimic acid coupled to dilute acid pretreatment. Applied Biochemistry and Biotechnology 162 (6): 1660-1668. - doi: 10.1007/ S12010-010-8947-7

Mc Nabb K, VanderSchaaf C (2005). Growth of graded sweetgum 3 years after root and shoot pruning. New Forests 29 (3): 313-320. - doi: 10.1007/s11056-004-5654-7

McConnell TE, Shi SQ (2011). Partially hydrolyzing southern hardwoods: possibilities for biofuels and wood composite manufacturing. Forest Products Journal 61 (3): 235-239. - doi: 10.13073/ 0015-7473-61.3.235

Meadows JS, Stanturf JA (1997). Silvicultural systems for southern bottomland hardwood forests. Forest Ecology and Management 90 (23): 127-140. - doi: 10.1016/S0378-1127(96)03898-4 Merkle S, Cunningham M (2011). Southern hardwood varietal forestry: a new approach to short-rotation woody crops for biomass energy. Journal of Forestry 109 (1): 7-14. [online] URL: http://www.ingentaconnect.com/content/ saf/jof/2011/00000109/00000001/art00004

Mitchell R, Zutter B, Green T, Perry M, Gjerstad D (1993). Spatial and temporal variation in competitive effects on soil moisture and pine response. Ecological Applications 3 (1): 167-174. - doi: 10.2307/1941799

Nelson LE, Switzer GL (1990). Sweetgum half-sib seed source response to nitrogen and phosphorus fertilization in Mississippi. Soil Science Society of America Journal 54 (3): 871-878. doi: $10.2136 /$ sssaj1990.03615995005400030043 $\mathrm{x}$

Nelson LE, Switzer GL (1992). Response of nine- year-old plantation sweetgum to nitrogen fertilization in Mississippi. Southern Journal of Applied Forestry 16 (3): 146-150. [online] URL: http://www.ingentaconnect.com/content/saf/sj af/1992/00000016/00000003/arto0010

Nelson LE, Switzer GL, Shelton MG (1995). Aboveground net primary productivity and nutrient content of fertilized plantation sweetgum. Soil Science Society of America Journal 59 (3): 925932. - doi: 10.2136/sssaj1995.0361599500590003 $0043 \mathrm{x}$

Nelson L, Ezell A, Yeiser J (2006). Imazapyr and triclopyr tank mixtures for basal bark control of woody brush in the southeastern United States. New Forests 31 (2): 173-183. - doi: 10.1007/ s11056-005-0925-5

Nikolaeva MG (1969). Physiology of deep dormancy in seeds. Izdatel'stvo Nauka, Leningrad, Russia, pp. 220.

Norby RJ, Iversen CM (2006). Nitrogen uptake, distribution, turnover, and efficiency of use in a $\mathrm{CO}_{2}$-enriched sweetgum forest. Ecology 87 (1): 5-14. - doi: 10.1890/04-1950

Ocsel H, Teke Z, Sacar M, Kabay B, Duzcan SE, Kara IG (2012). Effects of oriental sweet gum storax on porcine wound healing. Journal of Investigative Surgery 25 (4): 262-270. - doi: 10.3109/08941939.2011.639847

Orsted AS (1863). L'Amérique centrale: recherches sur sa flora et sa géographie physique. Résultats d'un voyage dans les états de Costa Rica et de Nicaragua exécuté pendant les années 1846-1848 [Central America: research on its flora and its physical geography. Results from a trip in the states of Costa Rica and Nicaragua executed during the years 18461848]. B. Luno par FS Muhle, Copenhagen, Denmark, pp. 18. [in French]

Perry M, Mitchell R, Zutter B, Glover G, Gjerstad $D$ (1994). Seasonal variation in competitive effect on water stress and pine responses. Canadian Journal of Forest Research 24 (7): 14401449. - doi: 10.1139/×94-186

Porcher FP (1869). Resources of the southern fields and forests, medical, economical, and agricultural. Walker, Evans and Cogswell, Richmond, VA, USA, pp. 733.

Rieckermann H, Goldfarb B, Cunningham M, Kellison R (1999). Influence of nitrogen, photoperiod, cutting type, and clone on root and shoot development of rooted stem cuttings of sweetgum. New Forests 18 (3): 231-244. - doi: 10.1023/ A:1006621330099

Rink G, Dell T, Switzer G, Bonner F (1979). Use of the Weibull function to quantify sweetgum germination data. Silvae Genetica 28 (1): 9-12. [online] URL: http://silvaegenetica.com/filead min/content/dokument/archiv/silvaegenetica/2 8_1979/28-1-9.pdf

Ruiz-Sanchez E, Ornelas JF (2014). Phylogeography of Liquidambar styraciflua (Altingiaceae) in Mesoamerica: survivors of a Neogene widespread temperate forest (or cloud forest) in North America? Ecology and Evolution 4 (4): 311-328. - doi: 10.1002/ece3.938

Sannigrahi P, Hu F, Pu Y, Ragauskas A (2012). A novel oxidative pretreatment of loblolly pine, sweetgum, and miscanthus by ozone. Journal of Wood Chemistry and Technology 32 (4): 361375. - doi: $10.1080 / 02773813.2012 .698691$

Sassner P, Galbe M, Zacchi G (2008). Techno-eco- nomic evaluation of bioethanol production from three different lignocellulosic materials. Biomass and Bioenergy 32 (5): 422-430. - doi: 10.1016/j.biombioe.2007.10.014

Scott DA, Burger JA, Kaczmarek DJ, Kane MB (2004). Growth and nutrition response of young sweetgum plantations to repeated nitrogen fertilization on two site types. Biomass and Bioenergy 27 (4): 313-325. - doi: 10.1016/j.biom bioe.2004.02.003

Shmulsky R, Saucier C, Howard I (2008). Composite effect of bolt-laminated sweetgum and mixed hardwood billets. Journal of Bridge Engineering 13 (5): 547-549. - doi: 10.1061/(ASCE)108 4-0702(2008)13:5(547)

Shmulsky R, Shi S (2008). Development of novel industrial laminated planks from sweetgum lumber. Journal of Bridge Engineering 13 (1): 64-66. - doi: 10.1061/(ASCE)1084-0702(2008)13:1 (64)

Sommer HE, Brown CL (1980). Notes: embryogenesis in tissue cultures of sweetgum. Forest Science 26 (2): 257-260. [online] URL: http:// www.ingentaconnect.com/content/saf/fs/198o/ 00000026/00000002/artoo014

Sova M (2012). Antioxidant and antimicrobial activities of cinnamic acid derivatives. Mini Reviews in Medicinal Chemistry 12 (8): 749-767. doi: $10.2174 / 138955712801264792$

Speck FG (1941). A list of plant curatives obtained from the Houma Indians of Louisiana. Primitive Man 14 (4): 49-73. - doi: 10.2307/3316460 Sullivan J, Lagrimini LM (1993). Transformation of Liquidambar styraciflua using Agrobacterium tumefaciens. Plant Cell Reports 12 (6): 303-306. doi: 10.1007/BFo0237423

Sutter E, Barker P (1985). In vitro propagation of mature Liquidambar styraciflua. Plant Cell, Tissue and Organ Culture 5 (1): 13-21. - doi: 10.1007/ BFoo033565

TMS (2010). 1st quarter 2010. Timber Mart-South Market News Quarterly, vol. 15, no. 1.

TMS (2014). 1st quarter 2014. Timber Mart-South Market News Quarterly, vol. 19, no. 1, pp. 52. [online] URL: http://www.timbermart-south.co m/pdf/1Q2014news.pdf

Uemura K (1983). Late Neogene Liquidambar (Hamamelidaceae) from the southern part of northeast Honshu, Japan. Memoirs of the National Science Museum 16: 25-36.

Wang $H$, Srinivasan $R$, $Y u F$, Steele $P$, Li Q, Mitchell B, Samala A (2012). Effect of acid, steam explosion, and size reduction pretreatments on bio-oil production from sweetgum, switchgrass, and corn stover. Applied Biochemistry and Biotechnology 167 (2): 285-297. - doi: 10.1007/s12010-012-9678-8

Wendling I, Brondani G, Dutra L, Hansel F (2010). Mini-cuttings technique: a new ex vitro method for clonal propagation of sweetgum. New Forests 39 (3): 343-353. - doi: 10.1007/s11056-0099175-2

Wenger KF (1953). The sprouting of sweetgum in relation to season of cutting and carbohydrate content. Plant Physiology 28 (1): 35-48. - doi: 10.1104/pp.28.1.35

Wetzstein HY, Sommer HE (1982). Leaf anatomy of tissue-cultured Liquidambar styraciflua ( $\mathrm{Ha}$ mamelidaceae) during acclimatization. American Journal of Botany 69 (10): 1579-1586. - doi: $10.2307 / 2442913$ 
Williams JW, Shuman BN, Webb T III, Bartlein PJ, Leduc PL (2004). Late-Quaternary vegetation dynamics in North America: scaling from taxa to biomes. Ecological Monographs 74 (2): 309334. - doi: 10.1890/02-4045

Wolfe JA (1985). Distribution of major vegeta tional types during the Tertiary. Geophysica Monograph Series 32: 357-375. [online] URL: http://onlinelibrary.wiley.com/doi/10.1029/GMo 32p0357/summary

Wright J, Cunningham M (2008). Sweetgum plantations for sawtimber, energy, pulp, and other uses. Forest Landowners 67 (3): 26-28. Wright HJ (1981). Vegetation east of the Rocky Mountains 18.000 years ago. Quaternary Research 15 (2): 113-125. - doi: 10.1016/0033-5894 (81)90099-5

Wu C, Dixon G, Muench S, Sandberg C (1983). The use of glyphosate for pine release in the Midsouth. Proceedings of the Southern Weed Science Society 36: 230-234.

Wyman CE, Spindler DD, Grohmann K (1992). Simultaneous saccharification and fermentation of several lignocellulosic feedstocks to fuel ethanol. Biomass and Bioenergy 3 (5): 301-307. doi: 10.1016/0961-9534(92)90001-7

Yang B, Wyman CE (2008). Pretreatment: the key to unlocking low- cost cellulosic ethanol. Biofuels, Bioproducts and Biorefining 2 (1): 26 40. - doi: $10.1002 / b b b .49$

Zhao X, Cheng K, Liu D (2009). Organosolv pretreatment of lignocellulosic biomass for enzymatic hydrolysis. Applied Microbiology and Biotechnology 82 (5): 815-827. - doi: 10.1007/s002 53-009-1883-1 